\title{
Covid-19 Experiences: A Call for Functional Education in Developing Countries
}

\author{
Onoshakpokaiye, E. Odiri ${ }^{1}$ \\ ${ }^{1}$ Institute of Education, Delta State University, Abraka, Delta State, Nigeria \\ Correspondence: Onoshakpokaiye, E. Odiri, Delta State University, Abraka, Delta State, Nigeria. \\ Email: onos68@yahoo.ca
}

Doi: 10.23918/ijsses.v7i3p29

\begin{abstract}
Leaders are elected to govern the citizens, and to ensure they provide all the necessary essential social amenities for them. With the emergence of covid-19 pandemic experience, there has been a great problem in fighting this disease by some of the developing countries especially Nigeria. The numbers of infected persons get increasing everyday due to insufficient personnel, facilities and few testing centres to help curtail this fearful covid-19 pandemic. The success of any nation in tackling major problems when it arises such as pandemic, poverty, inequality among others can be traced to good functional education. The reason for the increase of the infected persons, may be due to lack of functional education. The government failed to fund and make necessary provision for education to make it functional and also the health sectors are neglected. Every nation needs functional education for all round development. The paper looked at the definition of pandemic briefly. Education and functional education, educational challenges as result of covid19 pandemic, problem with online learning were discussed, while some problems and the way forward were also looked into.
\end{abstract}

Keywords: Covid-19, Pandemic, Functional Education, Developing Countries

\section{Introduction}

There is panic all over the world as a result of the disease called Covid -19 pandemic. There is confusion and economic breakdown due to Covid-19 virus. Schools were closed to reduce the spread. Before we discuss the present problem of Covid -19 pandemic as a ravaging disease that has resulted to the death of many and crippled many nations economy all over the world, let's look at some of the terms related to it. An outbreak is a situation when an illness happens in high numbers that is not expected. The illness may stay in one particular area or spread more widely, and it can last for days or years (WebMD, 2020). An epidemic is a situation when an infectious disease spreads rapidly to more people than what would be expected by experts and this usually affects a larger area than an outbreak (WebMD, 2020).

According to Wikipedia (2020) "A pandemic is an epidemic of an infectious disease that has spread across a large region. It is an epidemic occurring on a scale that crosses international boundaries, usually affecting people on a worldwide scale." WebMD (2020), defined pandemic "as a disease outbreak that spreads across countries or continents. It affects more people and takes more lives than an epidemic. The World Health Organization (WHO) declared COVID-19 to be a pandemic when it became clear that the illness was severe and that it was spreading quickly over a wide area." According to WHO (2020):

"Coronavirus disease (COVID-19) is an infectious disease caused by a newly discovered coronavirus. Most people infected with the COVID-19 virus will experience mild to moderate respiratory illness and recover without requiring special treatment. Older people, 
and those with underlying medical problems like cardiovascular disease, diabetes, chronic respiratory disease, and cancer are more likely to develop serious illness."

It mainly spreads through droplets of saliva or discharge from the nose of an infected person when he/she coughs or sneezes.

Leaders and heads of government all over the world are confused and as result imposed lockdown in their various countries due to Covid-19 pandemic. People can no longer visit one another, go to work, attend school, go to worship centres and even meet one another in public places because of lockdown. People in panic everywhere, struggling in their different homes. Some are in care homes and intensive care units, separated from their loved ones when they needed them most (Dennis, 2020). Everyone is deprived of every means of physical contact for the fear of being infected by the pandemic and possible spreads. According to Dennis (2020) "We are confronted with the true uncertainty of human existence and the true vulnerability of human life. How often have so many of us believed that we are supreme masters of the world around us." Most of the leaders and heads of government believed and felt that they are supreme masters, regarding other citizens as irrelevant and not important. They believed that they can do without them, the essential amenities and services like functional education, good health care services that are needed by the citizens are not being provided. With Covid -19 experience the leaders are now realizing that no one is immune to diseases or pandemic and that there is need for these essential services. What to do in this face of disease, became a problem because the facilities needed by some of these developing countries such as Nigeria, to curtail or fight this fearful disease are not on ground and this became a problem due to total neglect by the government. They are now running from pillars to poles in order to proffer lasting solution to this fearful and deadly disease. How can the solution come when the other citizens are not valued, and their right are being deprived?

According to Dennis (2020):

"The Coronavirus shows us how terrible it really is to waste our lives, embroiled in endless battles for wealth and status and power. How terrible it really is not to recognize the value in the people around us - not just our family and friends, not just colleagues and fellow citizens, but also complete strangers.

The experience of Covid -19 has become an eye opener and great lesson to those in authorities who accumulates wealth for themselves, their families at the expense of the masses and failed to provide the essential amenities and other developmental infrastructures for their citizens. A tree cannot make forest as they say. Every individual is needed for proper functioning of any country. Dennis (2020) went further to say that "How terrible it is not to give our lives meaning - every hour of every day - by honouring the sacredness of life and according all living things the respect, sensitivity and care that they deserve." Every human need to be accorded of what is due to them, not minding their status, for proper functioning of the society. Covid- 19 experience has enabled those in authorities to recognize the usefulness of providing functional education, new technologies and other social amenities to serve human needs and purposes. Dennis (2020) has this to say "it shows us the importance of recognizing the true purpose of all our businesses and economies, our political parties and governments, our local civic associations and our international organizations, our conventions and ideologies, and all our other systems: namely, to serve human needs and purposes." For any nation to have all round development, training and retraining of her 
citizens cannot be overlooked. For proper functioning of any nation every sectors of the country economy need to be well balanced and this can only take place through functional education. To effectively fight this dreaded Covid- 19 disease calls for the application of all the knowledge and skills acquired through education which can only be achieved through functional education.

\section{Concept of Education}

No nation can develop without involving her citizens. Abid (2006) stated that quality of a nation depends upon the quality of her citizen and the quality of citizens depends on the quality of their education. According to Ebuta (2017):

"Education is an instrument for national development which is a veritable means of socioeconomic growth. All-over-the world, education is a powerful instrument of change. In education there is the formation of ideas, where their integration for national development is very essential"

Asaju and Adagba(2014) stated that "Education is the bedrock of the socio-economic and political development of any nation." Education is a pivotal of national growth and wellbeing of the citizen of any nation. According to Nigeria Minister of Education, Adamu (2018)

"It is disturbing that despite the immense human and material resources Nigeria is endowed with, the country is still firmly handicapped and unable to wriggle her way out of entrenched developmental quagmire. Aside from the retinue of our moral woes, the biggest indictment comes from a failing educational system."

The Nigeria National policy on education (NPE) stated the educational objectives and how it can be achieved. Some of the specific goals as stated in NPE are as follows: to ensure delivery of quality of education at all levels; promote functional education for acquiring skills, creation of job and reduction of poverty; ensure periodic review, effectiveness and relevance of the curriculum at all levels to meet the societal needs and the world of work (FGN, 2013).

\section{Concepts of Functional Education}

Asaju et al (2014) stated that "Functional education is quite different from the concept of education. While education simply refers to the process by which knowledge and skills are acquired, functional education is more encompassing, meaningful and most desirable." Functional education means education,that is capable of assisting the citizens to the full realization of their potentials and also be able to contribute using these potentials for the improvement and development of the nation (Ebuta, 2014). Functional education is the education where students acquire the needed knowledge and functional skills for the performance of productive tasks for proper functioning in the society and also contributing to the development of the society and meeting up the needs of the society.

Good cited in Asaju et al (2014), defines functional education as "Education for which there is an anticipated application, which thus assumes that the learner has immediate meaning, transferable into action of his learning activities." In functional education more emphasis is placed on the students' ability to perform productive tasks, it lays more emphasis on practical rather than theory. Education in Nigeria 
and some other developing countries are not functional in the sense that too much emphasis is placed on theoretical work and academic knowledge instead of practical or skills acquisition. In Nigeria much emphasis is on possession of certificates rather than what the person can do (Cookey in Asaju et al, 2014). The implication of this non-functional education is turning out graduates without skills and knowledge and at the end, they cannot contribute and apply their knowledge acquired from the university to the needs of the society.

For any educational system to be regarded as functional, it should have the ability and capacity to ensure there are food sufficiency, enough employment, good health care services and also provide other services desirable to the people and enthronement of democracy (Ebuta, 2014). Functional education is the education that has the ability to transform a nation's economy from a consumer to a manufacturer of goods. According to Ebuta (2017) functional education to some scholars implies an education which put a country in a position of being a manufacturer of raw materials such, as machines and industrial tools for production in the industries. They should be able to produce enough food for both domestic and international consumption. And also, should be able to invent or discover and manufacture drugs capable enough in curing diseases.

\section{Educational Challenges as Result of Covid-19 Pandemic}

The COVID-!9 pandemic has greatly affected and disrupted many nations educational systems and it has resulted to near-total closures of schools at all levels, this includes primary, secondary and the tertiary institutions in order to curtail its spread (UNESCO. 2020a, wikipedia,2020). According to UNESCO (2020a). "These nationwide closures are impacting over $60 \%$ of the world's student population. Several other countries have implemented localized closures impacting millions of additional learners." Many countries temporarily shut down all schools at different levels of their educational systems so as to curtail the spread and possible infection of the corona virus disease. Wikipedia (2020), stated that "As of 27 July 2020 , approximately 1.725 billion learners are currently affected due to school closures in response to the pandemic." In order to curtail the global pandemic, governments all over the world decided to close educational institutions and the number of children, youth and adults who are not attending schools or tertiary institution are increasing as result of COVID-19 pandemic (UNESCO,2020b). UNESCO (2020b) stated further "According to UNESCO monitoring, over 100 countries have implemented nationwide closures, impacting over half of world's student population. Several other countries have implemented localized school closures and, should these closures become nationwide, millions of additional learners will experience education disruption."

Many external, international, professional and other examinations were cancelled in order to prevent possible infection and spreading of the pandemic through students. Cambridge international examinations (CIE) on $23^{\text {rd }}$ march, 2020 brought out a statement as regard the cancellation of different examinations that are being conducted by them (wikipedia,2020). Many other examinations were also cancelled, the West African school certificate examination that are written by some West African countries were cancelled, they just started the examinations which supposed to have be written in May/June, on the $17^{\text {th }}$, August 2020 as a result of the pandemic. National Examination Council (NECO), Nigeria examination body was also cancelled which is yet to be written. Apart from these examinations body, there are other local, state examination and placement examination for students into tertiary institutions which are yet to 
be fixed due to this ravaging disease called Covid -19. To solve this problem of closure distance learning and online learning was introduced so that teachers can teach the students in order not to disrupt education system.

\section{Problems with Online Learning}

The effect of this school closures is more severe for the less privilege children and their families, causing interrupted learning, childcare problems, not feeding well and also affecting the families economic cost of those who could not work and even some were sacked as a result of total lockdown(UNESCO,2020a UNESCO,2020b, wikipedia, 2020). The socioeconomic status of parents may likely have negative impact on the education of the disadvantaged students. Many of the students are not participating in online teaching/learning, not that they don't have interest but as result of their family background and income of their parents. These children cannot afford what it takes to carry on or participate with the online learning. Before now most of the citizens live in hardship and poverty, so it became difficult for the parents to provide necessary learning facilities and materials for their children. The leaders themselves fail to procure the necessary learning facilities/materials to effectively implement the online teaching/learning. Many developing countries educational systems are not properly funded. They lack the basic facilities and new technology that will enable them implement and also for the students' participation on the online teaching/learning. It is now they are struggling and trying to procure some of the necessary facilities and new technologies to enable the students participate with the online learning which they are finding difficult, since their main focus for now is on how to fight the pandemic. Although there is government policy statement as per online learning, how can it be possible when the facilities and man powers are not available. Even the teachers who are supposed to implement the online are not trained, most of them don't even have good phones talking of laptop or computer systems.

Gaining access to the internet is another major problem to this online learning. Most of the schools including higher institutions do not provide internet services for their staff. Those staff who are computer literate pay for their own subscription from internet provider. Couple with these problems, most of the developing countries lack good power or electricity supply. Constant electricity supply is not available for those in the urban more or less those in the rural areas. With lack of good electricity how can online teaching/learning take place. It is a major problem and hindrance to the effective using of online to teach the students during this pandemic. Due to poverty level of the family, the students cannot afford 3 square meals, more or less payment of school fees or having the necessary facilities or materials necessary to access the internet for online teaching/learning. In addition, most of the villages have no light.

According to Aucejo, French, Ugalde \& Zafar (2020) "A team of researchers associated with Opportunity Insights found that students from lower income areas decreased their participation in online learning as the pandemic progressed (Chetty, Friedman, Hendren \& Stepner,2020)." It will be very difficult for the students to effectively participate in online learning when they lack good phones, laptop and computer system to access the internet. The closures of school affect mostly the disadvantaged students in this pandemic since they cannot afford what it takes to carry on with the learning. Aucejo, et al, (2020) stated that "the existing body of evidence paints a clear picture that the pandemic has been significantly more disruptive to disadvantaged students across all levels of education". The closure of schools as result of covid-19 has more impact on the education of the less privilege, because most of the public schools lack 
the internet facilities and computer experts to go on with the online learning. Students from the rich homes attend good private schools, have all the necessary technology or gadget and full access to the internet even before covid-19 pandemic and also the schools they attend have the internet facilities to carry on with online learning. These children from well to do homes are participating in the online or distance learning, therefore they did not miss as regard to learning when compared to disadvantaged ones.

The problem of the full implementation of the online teaching and learning is as result of lack of functional education. If the online learning or distance learning facilities are provided and the citizens are living well before this covid-19 pandemic, it would have been very easy for almost all the students to participate. There is need for functional education, this is a type of education where students are trained and acquire useful skills for the betterment of the nation. The teachers are not left out. If they are well trained with the relevant equipment, technology and other facilities or retrain them through workshops, seminars and others, the problem of most students and schools not participating in the online learning will not be there.

\section{Some Problems and Way Forward}

In realizing the potentials of the citizens, there is the need for functional education. Functional education enables the citizens of any nation to make full use of their potentials towards the improvement of the society and contribute meaningfully towards the all-round development of the country. It should be able to provide for the wellbeing and welfare of the citizens and help in the advances of science and technology which will eventually result to economic growth and the enhancement of democracy. It is therefore expected that functional education will promote the welfare of the citizens, economic growth and advancement of technology.

Emphasis should be placed on functional education curriculum. The curriculum should be reviewed to remove those topics that are obsolete while new topics that can transform the society should be included.

The federal and state government need to be committed towards education funding. Some of the problems Nigeria and other developing countries education encounter for not achieving or attaining functional education today is the lack of government commitment to funding. The schools should be properly funded to enable the teachers and lecturers carry out their duties effectively. Lack of funding is likened to farmer without farm tools. One of the reasons why Academic Staff Union of University (ASUU) in Nigeria university went on strike is the lack of commitment by the federal government towards the improvement of the university education. This is a place where students are trained in different fields on how to make use of their knowledge and skills to discover any diseases and the production of drugs to fight diseases. They have been on strike even at this present time of covid -19 pandemic when the nation needed them most. Most of the facilities and equipment are obsolete where they exist. No good laboratories to carry out research work. Most of the hospitals are ill equipped. There is no research grant for the lecturers and students to carry out research work.

Many leaders/ heads of government are now crying and complaining about the everyday increase of covid -19 infected persons. Why will it not increase when there are no proper or enough qualified personnel and health workers to carry out this duty. Why will there not be an increase when there are few testing centres. In fighting this deadly and infectious Covid -19 virus, there is need for enough good testing centres, enough scientists, laboratory technologists, sufficient doctors and other health workers. But how can this be 
achieved? It can only happen when the educational systems are functional. With this Covid -19 experience, the federal government can now see the need for proper funding of education, train and retraining of doctors and other health workers. The students need to the trained with modern equipment to meet up with the present-day challenges.

Hospitals should be well equipped with the modern-day facilities so that in future occurrence of similar situation they will be able to curb it to the barest minimal. Most of the hospitals are not properly taken care of, because the president, senators, governments officials and the wealthy ones put their hope in foreign hospitals for checkup and treatments. They travel abroad at will for medical treatment or checkup, for this reason they pay deaf ears to the improvement of health sectors and funding of the university education whenever the doctors, lecturers and masses are crying. Forgetting that they were elected to provide all the essential amenities for the citizens. But now it has happened who is to be blamed and where will they run to? These hospitals whether teaching hospital or other hospital need to be upgraded and there should be proper training of doctors and other related fields. The government should know that these students need to be well trained with good hospital equipment and other relevant facilities so that there can be good laboratory technologists, nurses and doctors. The government should realize that after university training it is the hospital where students carry out their practical to gain experience.

Primary and secondary schools' education are not left out of these problems, because this is where all education foundation is laid. They should also be properly funded with modern days facilities, good infrastructures, teachers should be motivated to carry out their work effectively. There is also the need to provide a conducive learning environment for the teachers, pupils and students. According to Ebuta (2017) "The impact of inadequate educational facilities in the education of students creates a gap which makes students end up not acquiring skills needed to get into the labour market." Priority should be given to curriculum implementation in order to attain a functional education. Some of the problems facing the nation educational system in attaining functional education today is lack of curriculum implementation. Adamu (2018), the Minister of education, stated that the problem of education in Nigeria, is not there is no good policy in the national policy on education (NPE). The policy was developed by some intelligent education experts which take care of the lower level to the tertiary levels of education. According to him "Good ideas only - often not backed with the requisite impetus necessary to bring about transformation." According to Enaibe (2011) the kind of curriculum that is operational in the school system today "does not promote human resources capacity development". No educational system can rise above the quality of its teachers and so quality of teachers is a must for the education to be functional. There is need for the educational system to produce highly qualified, motivated conscientious and efficient classroom teachers for all the levels of the educational system and when this is done, there will be an improvement of skills and knowledge transfer. Qualified mathematics teachers should be employed to develop in the students, critical, reasoning and creative thinking, since it is the subject for developing critical and reasoning skills. Ebuta (2014) stated that instruction need to be modified in ways that are consistent with the development of critical and creative thinking in the learner.

The government should ensure that the teachers are provided with the new technology and also make sure internet services are made available for the staff and students. This will help the teachers and students when this type of situation of school closures arises again. 
This lack of functional education is common to most developing countries. Some of the government officials are particular about themselves and their family. Other citizens are being neglected in the provision of essential amenities such as functional education and provision of good health facilities.

\section{Conclusion}

Education is one of the essential responsibilities of any nation to her citizens. Providing good education to the citizens leads to improvement and development of every nation. Where there is no functional education, that society is bound to be backward economically, scientifically and technologically. The developed countries we heard of today did not just get to where they are, it is as a result of functional education. In curbing any diseases or pandemic, functional education must be needed. Some of those developed nations that were able to fight this covid-19 pandemic to some extent today, even though not completely, is as result of functional education and the importance their leaders placed on education and health sectors. Therefore, it is of great importance for the leaders to put their citizens at heart in policy making. This also calls for urgent attention of the government to ensure that the necessary social amenities needed by the citizens to enable them to contribute to the economic growth and other area of national development should be provided.

\section{References}

Abid, H. C (2006). Effects of Guidance services on study attitude, study habits and Academic achievement of secondary school students. Bulletin of Education and Research, 28(1) 35-45.

Adamu, A. (2018) In pursuit of functional education. The Punch Newspaper online https://punchng.com/in-pursuit-of-functional-education/ September 28, 2018.

Asaju, K., \& Adagba, S.O. (2014) .Functional education in Nigeria: a catalyst for effective poverty alleviation. Research Journal in Organizational Psychology \& Educational Studies (Rjopes) 3(4), 313-318.

Aucejo, E., French, J., Ugalde, P. A., \& Zafar, B. (2020). COVID-19 is widening inequality in higher education. Retrieved 19, August, 2020.

Chetty, R., Friedman, J.N., Hendren, N., \& Stepner, M. (2020), "How Did COVID-19 and Stabilization Policies Affect Spending and Employment? A New Real-Time Economic Tracker Based on Private Sector Data".

Dennis J. S. (2020). Fundamental lessons from the Covid-19 pandemic. Opening Address of the Global Solutions Summit 2020. https://www.global-solutions-initiative.org/press-news/fundamentallessons-from-the-covid- 19-pandemic-global-solutions-summit-2020-opening-address/

Ebuta, E. E. (2014) Creativity and Innovation in Education: A philosophical Gap in Nigeria Educational System. Annual Book of Reading: Philosophy of Education Association of Nigeria (PEAN)

Ebuta, E. E. (2017) Creative and Functional Education in Nigeria: The Problem of Implementation Journal of Resourcefulness and Distinction, 15(1), 1-7.

Enaibe, P.U. (2011) Making Education Functional in the 21st Century. State of Affairs of the Nigerian Situation (ed) Egbule, P. Tabot, Dip J.E., \& Abohe. D.A. Refocusing Education in Nigeria in the 21st Century: Onitsha. Solomon West Press

Federal Government of Nigeria (2013). National Policy on Education (6 ${ }^{\text {th }}$ edition), Lagos: NERDC Press.

UNESCO (2020a). Education: From disruption to recovery. Retrieved 19, August 2020 from https://en.unesco.org/covid19/educationresponse

UNESCO (2020b). Educational disruption and Response. Retrieved 19, August, 2020 from https://en.unesco.org/news/covid-19-educational-disruption-and-response 
WebMD (2020). Pandemics. Retrieved 15, May, 2020. https://www.webmd.com/cold-and-flu/what-areepidemics-pandemics-outbreaks Wikipedia (2020). Pandemics. Retrieved 19, august 2020 from https://en.wikipedia.org/wiki/Pandemic\#Definition World Health Organization (WHO).

Coronavirus. Retrieved 18, May 2020 from https://www.who.int/health-

topics/coronavirus\#tab=tab_1 